\title{
Do we need to include anthropogenic land-use and land-cover changes in paleoclimate simulations?
}

\author{
Sandy P. Harrison', B.D. Stocker², K. Klein Goldewijk ${ }^{3}$, J.O. Kaplan ${ }^{4,5}$ and P. Braconnot ${ }^{6}$
}

\section{We motivate and describe the minimum set of data required to improve the modeling of feedbacks associated with land-cover and land-use changes on climate over the Holocene.}

The paleoclimate modeling community is gearing up for a new set of analyses of past climate change as part of the current phase of the Coupled Model Intercomparison Project (CMIP6). The role of land-surface feedbacks on climate will be a major focus of these analyses. Assessment of the importance of human impacts on land use and land cover (LULC) for climate during the industrial period have been hampered by uncertainties about the nature and size of these changes and by differences in the way LULC changes are implemented in models. The climate impact of LULC changes before the industrial period is also a matter of debate. Here, we examine why we need to include anthropogenic LULC changes in paleoclimate experiments and the key data requirements for doing so.

\section{What is LULC change and how \\ does it affect climate?}

Climate-induced changes in land cover during the last century have been small, and largely confined to increased productivity and shifts in growing-season length. However, human activities during the industrial period have profoundly changed terrestrial landscapes, by removing natural vegetation for agriculture and husbandry, and through more subtle changes in structure and composition of the veg etation caused by management practices. Anthropogenic LULC changes affect climate through changes in the carbon cycle resulting from modifications in vegetation and soil carbon storage (biogeochemical feedbacks) and through changes in the surface-energy budget resulting from modifications of surface albedo, evapotranspiration, and canopy structure (biophysical feedbacks). About one third of the total anthropogenic $\mathrm{CO}_{2}$ emissions during the industrial period have been attributed to LULC changes, while biophysical effects have contributed to cooling extra-tropical regions and warming the tropics (Myhre et al. 2013). However, large differences between reconstructions of the extent of agricultural and grazing land prior to industrialization (Fig. 1) imply significant uncertainty in anthropogenic climate forcing during the historical period (Stocker et al. 2018).

\section{Early agricultural impact on climate?}

There is archaeological and palynological evidence from many parts of the world for human-induced landscape changes during the Late Holocene. This raises the issue of whether the LULC changes associated with the Neolithic agricultural revolution, from ca 10,000 year BP onwards in the Middle East, were large enough to affect climate. The idea that greenhouse gas emissions associated with Neolithic LULC changes were sufficiently large to offset climate cooling (the overdueglaciation hypothesis: Ruddiman 2003) has been challenged on multiple grounds (e.g. EPICA Community Members 2004; Stocker et al. 2017) but a LULC impact on climate in more recent millennia appears more plausible. Model studies have shown that prescribed Holocene LULC changes had detectable impacts on regional temperature and precipitation and even had a significant effect beyond the major agricultural regions (e.g. Smith et al. 2016). However, reconstruc tions of pre-industrial LULC change (Klein Goldewijk et al. 2011; Kaplan et al. 2011; Klein Goldewijk et al. 2017) are based on estimates of past population and the timing of first agriculture, and simple assumptions about the cropland and pasture area required per person, derived from relatively well-documented regions and extrapolated to the rest of the world. Large uncertainties in all of these factors translate into widely different land-use
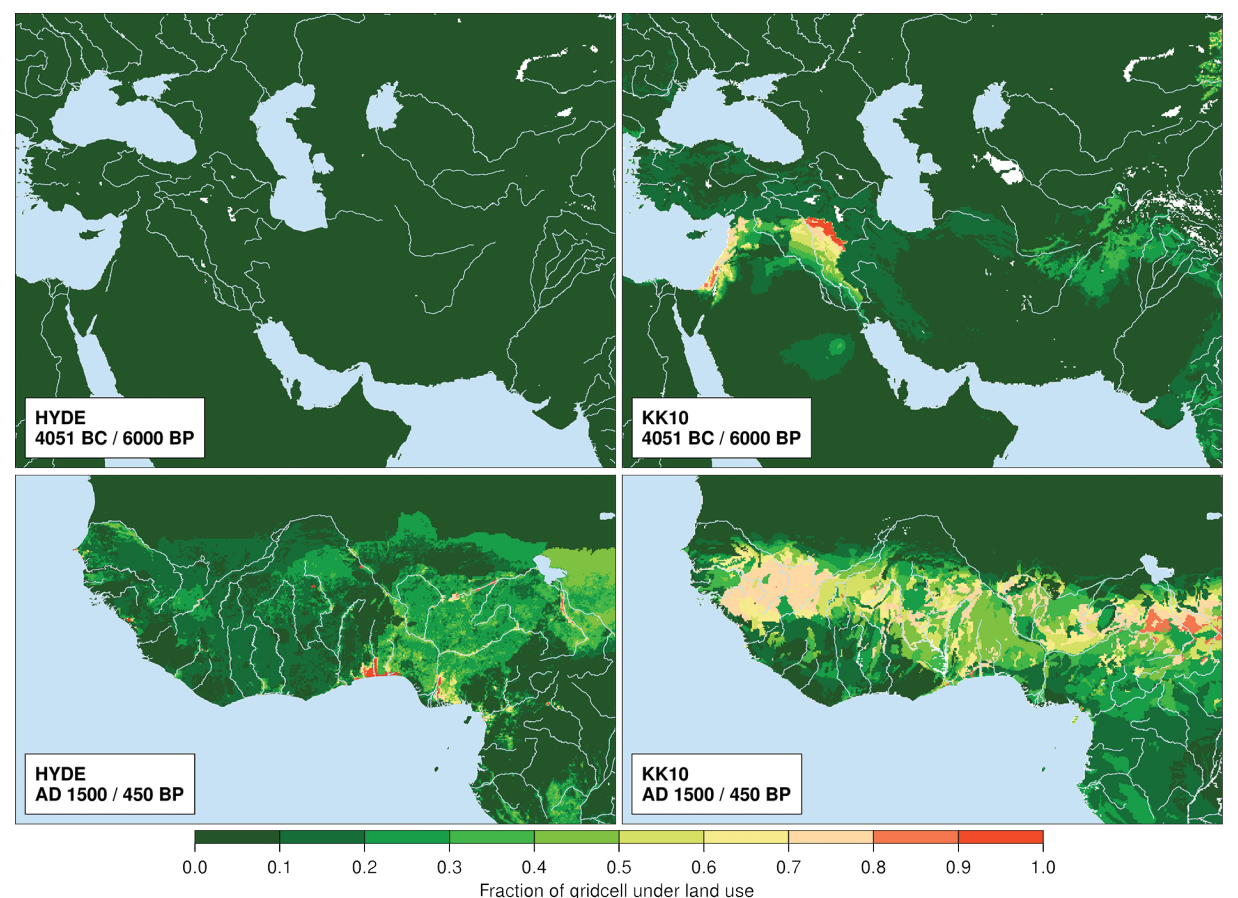

changes: Minimum requirements for paleoclimate modeling

The vegetation module of Earth System Models (ESMs) predicts the natural vegetation response to changes in simulated climate and $\mathrm{CO}_{2}$. LULC changes are treated as external forcing and used to modify the simulated natural vegetation distribution by specifying the area of each grid cell at each time occupied by crop or pasture plant functional types. Changes in cropland and pasture area involve a redistribution of carbon, nitrogen and water mass between these different areas (or "tiles") and between product pools within the grid cell. This, and prescribed management (e.g. soil cultivation, implemented by enhancing soil organic matter decomposition rates; removal of material from cropland and pasture (harvest), implemented by diverting a fraction of aboveground biomass into respiration) determine the carbon balance of each grid cell. Typically, cropland management has a stronger impact on reducing soil carbon

Figure 1: Land use in the Middle East (top panels) at 6000 year BP and West Africa (bottom panels) at AD 1500, from the two widely used global historical land-use scenarios HYDE 3.2 (left panels, Klein Goldewijk et al. 2017) and KK10 (right panels, Kaplan et al. 2011), illustrating the large disagreement between LULC scenarios at a regional scale. 
Land use transition State after transition
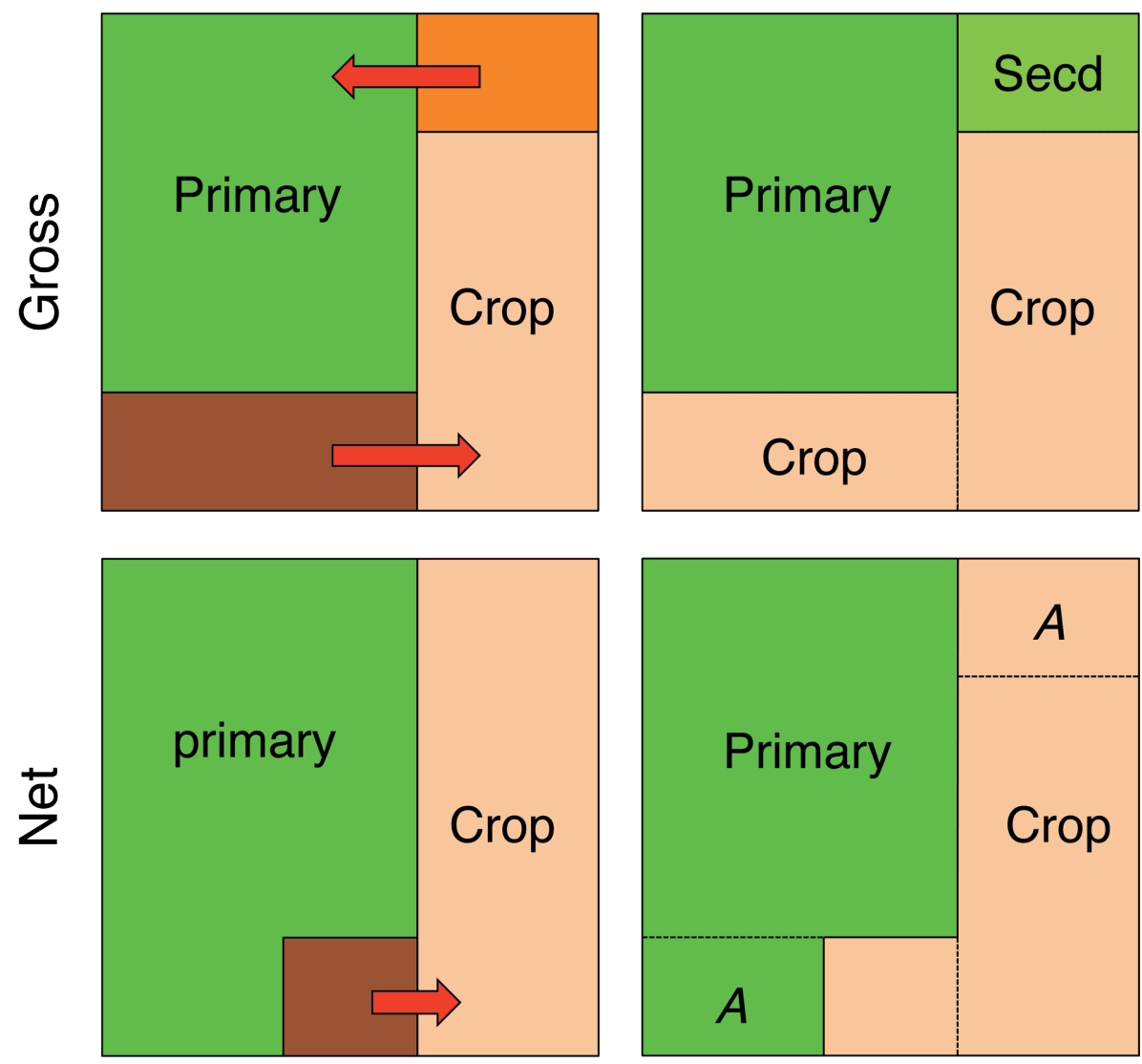

Figure 2: Schematic illustration of simulating gross (top row) versus net (bottom row) LULC change within one grid cell (modified from Stocker et al. 2014). The orange area represents abandonment of cropland and the brown area represents conversion of forest to cropland. In the scheme for gross LULC, abandoned cropland is treated as a separate land unit for secondary land ("secd"). In the scheme for net LULC, only the net land-use change (conversion of primary minus abandonment of cropland) is accounted for and no area of secondary regrowth is created. Note that $A$ denotes equal areas. As a result, a smaller grid-cell-area fraction is affected by LULC in the net scheme compared to the gross scheme and biomass stocks are on average smaller in the gross scheme due to younger vegetation on secondary land.

storage than grazing. The treatment of pasture, and particularly whether pasture expansion results from conversion of forests or naturally open vegetation, varies between ESMs, and has strong effects on simulated LULC $\mathrm{CO}_{2}$ emissions.

LULC changes are bi-directional: land can go from natural vegetation to crop or pasture, but cropland and pasture can also be abandoned and revert to natural vegetation (Fig. 2). This secondary growth (whether forest or openland) does not necessarily have the same characteristics and carbon balance as undisturbed natural vegetation. Accounting for these total (or "gross") LULC changes (e.g Shevliakova et al. 2009) is particularly important in regions of shifting cultivation and has been shown to increase $\mathrm{CO}_{2}$ emissions over the past 150 years by ca 10-40\% (Arneth et al. 2017). However, accounting for gross LULC changes requires additional information about land turnover rates and the time-varying extent of shifting cultivation.

The productivity of natural vegetation can be affected by management, most importantly wood harvesting for construction or fuel. Wood harvesting further inflates total $\mathrm{CO}_{2}$ emissions from LULC changes, with effects during the historical period similar in magnitude as those of shifting cultivation (Arneth et al. 2017). Implementation in models requires additional information on either the area affected by, for example, clear cutting or the amount of biomass removed by grid cell.

Thus, technically, the minimum set of information required to be able to model the impact of LULC changes in paleoclimate experiments is:

- Cropland areal fraction;

- Pasture areal fraction;

-Whether pasture has been converted from natural forest or from open vegetation;

- The fraction of biomass removed each year by crop harvest;

- The fraction of aboveground biomass removed each year by livestock on pastures;

- Land turnover rate under shifting cultivation;

- Time-varying extent of shifting cultivation;

- The amount of biomass removed or area affected each year by wood harvesting.

\section{The PMIP4-CMIP6 experiments}

The evaluation of paleoclimate simulations provides an out-of-sample test of the models used to project the future, and paleoclimate experiments are therefore included as part of the suite of simulations in the current phase of CMIP6. The contribution of the Palaeoclimate Modelling Intercomparison Project (PMIP) to CMIP6 (PMIP4-CMIP6) will focus on a limited number of paleoclimate experiments. One of these simulations, the Last Millennium simulation (past1000, 8501850 CE; Jungclaus et al. 2017), will include prescribed time-varying LULC changes thus ensuring that the LULC forcing will mesh con tinuously with the LULC forcing being used for the 20th century. The baseline mid-Holocene simulation (midHolocene, 6000 year BP; Otto-Bliesner et al. 2017) will not include prescribed changes in vegetation cover or LULC, although some modeling groups will be running with interactive vegetation and thus will be able to examine the feedbacks associated with climate-induced changes in natural vegetation. Additional sensitivity experiments are planned to investigate the likely impact of both climate-induced vegetation changes and LULC changes on the mid-Holocene climate. Robust evidencebased reconstructions of vegetation and LULC changes are therefore an important contribution to the PMIP4-CMIP6 exercise. The challenge for the PAGES LandCover6k Working Group (http://pastglobalchanges. org/ini/wg/landcover6k) is to translate the still somewhat patchy observational records into a global gridded dataset in a timely way so that these sensitivity tests are more realistic than previous attempts to investigate LULC changes during the Holocene.

\section{AFFILIATIONS}

'School of Archaeology, Geography and Environmental Science, Reading University, UK ${ }^{2}$ Ecological and Forestry Applications Research Centre, Cerdanyola del Vallès, Spain

${ }^{3}$ Copernicus Institute of Sustainable Development, Utrecht University, The Netherlands

${ }^{4} \mathrm{Max}$ Planck Institute for the Science of Human History, Jena, Germany

${ }^{5}$ School of Geography and the Environment, University of Oxford, UK

${ }^{6}$ Laboratoire des Sciences du Climat et de I'Environnement, Gif-sur-Yvette, France

\section{CONTACT}

Sandy P. Harrison: s.p.harrison@reading.ac.uk REFERENCES

Arneth A et al. (2017) Nature Geosci 10: 79-84 EPICA Community Members (2004) Nature 429: 623-628 Gaillard M-J et al. (2010) Clim Past 6: 483-499

Jungclaus J et al. (2017) Geosci Model Dev 10: 4005-4033 Kaplan JO et al (2011) Holocene 21: 775-791

Klein Goldewijk K et al. (2011) Global Ecol Biogeogr 20: 73-86

Klein Goldewijk K et al (2017) Earth Syst Sci Data 9: 927-953

Myhre G et al. (2013) In: Stocker TF et al. Climate Change 2013: The Physical Science Basis. Cambridge University Press, 659-740

Otto-Bliesner B et al. (2017) Geosci Model Dev 10: 3979-4003

Ruddiman WF (2003) Clim Change 61: 261-293

Shevliakova E et al. (2009) Glob Biogeochem Cycles 23: GB2022

Smith MC et al. (2016) Clim Past 12: 923-941

Stocker BD et al. (2014) Tellus B 66: 23188

Stocker BD et al. (2017) PNAS 114: 1492-1497

Stocker BD et al. (2018) PAGES Mag 26(1): 6-7 